\title{
Analysis of Banking Efficiency in Indonesia (Case Study in General Bank of Business Activities Level 2 Go Public)
}

\author{
Ferry Ardiansyah* \\ School of Business \\ IPB University \\ Bogor, Indonesia \\ ferryard@gmail.com \\ Mulya E. Siregar \\ School of Business \\ $I P B$ University \\ Bogor, Indonesia \\ mesir57@gmail.com
}

\author{
Hermanto Siregar \\ Department og Economics, Faculty of \\ Economic and Management \\ IPB University \\ Bogor, Indonesia \\ hermantojsiregar@gmail.com
}

\author{
Dedi Budiman Hakim \\ Department og Economics, Faculty of \\ Economic and Management \\ $I P B$ University \\ Bogor, Indonesia \\ dedihakim@gmail.com
}

\begin{abstract}
This efficiency is a calculation of the ratio between input and output variables. This research is using non-parametric Data Envelopment Analysis (DEA) for General Banks of Business Activities (BUKU) level two banks registered at IDX with the period of analysis in 2014- 2018. To analyze its efficiency by using an intermediary approach, there are two variables that consist of input variables i.e. labor cost, third party funds and fixed asset, and the output variables i.e. total financing, operating income and current assets. The sample analysis is taken from all population banks in BUKU II that already Go Public, which consists of two sharia banks, and sixteen conventional banks (four foreign banks, one state-owned bank and eleven national private banks). The result of this study shown that foreign banks and the national private banks had consistency and a better level of efficiency compared to other bank during 2014-2018. Shariah bank was able to achieve the best level of efficiency (Bank BTPN Syariah in 2018). Most of the foreign banks were able to achieve a level of efficiency (Bank Woori Saudara in 2014 \& 2018, Bank QNB Indonesia in 2015 \& 2018, Bank of India in 2014, 2015 \& 2016). In the national private bank, there were only four banks that able to achieve, which were Bank Ina Perdana $(2014,2015,2016$ \& 2017) Bank Victoria (2017 \& 2018), Bank Nationalnobu (2014) and Bank Sinarmas (2016). There was no state-owned bank, in this achieved level of efficiency.
\end{abstract}

Keywords: banking efficiency, Data Envelopment Analysis, go public, intermediary approach

\section{INTRODUCTION}

\section{A. Background of Study}

Regional and dynamic global developments, as well as to support Indonesia's economic growth optimally and sustainable, are needed to increase the resilience, competitiveness and efficiency of the national banking industry. To increase the resilience, competitiveness and efficiency of national banks, it is necessary to restructure the scope of business activities and the opening of office networks that are adjusted to the bank's capital capacity.
This condition was taken into consideration by Bank Indonesia to issue Bank Indonesia Regulation No.14 / 26 / PBI / 2012 concerning Business Activities and Office Networks based on Bank Core Capital. In Article 3 of the provisions, this regulation classified Banks into 4 categories of General Banks of Business Activities (BUKU) based on core capital, namely:

1. BUKU 1 is a Bank with a Core Capital of $<\mathrm{Rp} 1$ trillion.

2. BUKU 2 is a Bank with Core Capital between IDR 1 trillion - IDR 5 trillion.

3. BUKU 3 is a Bank with Core Capital between IDR 5 trillion - IDR 30 trillion.

4. BUKU 4 is a Bank with a Core Capital $>=$ IDR 30 trillion.

The development of banking in BUKU 2 shows diverse dynamics in both conventional banks and sharia banks during the period of 2015 - 2018. Together with the growth of financing or credit and third party fund collection that occurs in BUKU 2 of conventional banks and sharia banks has caused an impact in financing to deposit ratio (FDR) ratio. In BUKU 2 conventional banks, an average FDR during 2015 - 2018 has reached $95.27 \%$, whilst for sharia banks have reached $84.61 \%$. The increase raised on sharia Bank third party from 2017 to 2018 , certainly has an impact on the high cost of funds for sharia banks in BUKU 2.

The impact of these developments is further seen from the development of profits obtained in sharia banks which larger than conventional banks. In conjunction with the increase in performance obtained by BUKU 2 conventional banks and sharia banks, capital has also increased. The biggest increase occurred in sharia banks compared to conventional banks. Furthermore, several financial ratios at BUKU 2 banks are presented in the following Table 1.

Regarding operational management, the increase in operational costs of BUKU 2 sharia banks is greater than conventional banks. On average during 2014 - 2018, the 
increase in operational costs in sharia Banks was $10.91 \%$, much higher than conventional banks which on average during 2014 - 2018 were able to reduce operating costs by $0.64 \%$. However, the increase in operational costs was also followed by an increase in the operating income of sharia banks which was larger than conventional banks. Sharia banks have been able to increase the average operating income in $2014-2018$ by $15.09 \%$, which is greater than conventional banks whose average dropped by $-0.94 \%$. This is certainly a challenge on how efficient efforts are made both by conventional banks and sharia banks that can be done to be able to manage their operations efficiently.

For this reason, it is necessary to conduct a more strategic study related to the level of efficiency that exists in the bank groups in BUKU 2. In the end, banks, especially banks in BUKU 2 categories, need to find a strategy to be able to increase revenue and to be able to improve their performance to compete with other banks. This trend encourages this research to carried out analysis of efficiency and determination of strategies in the bank groups in BUKU 2 from the perspective of practical banking applications and practices that will create and guarantee the sustainability of banks in Indonesia.

\section{B. Objective and Potential Contributions}

Until June 2019, there are 59 banks in BUKU 2 bank categories. Based on data obtained from the Indonesia Stock Exchange, there are eighteen banks in BUKU 2 classified as of them public companies or go public with variable core capital of Rp.1 trillion to under of Rp.5 trillion. To conduct an analysis of efficiency analysis in BUKU 2 bank group, especially for BUKU 2 banks that already go public. The following is a summary of the financial ratios for the eighteen banks as in Table 2.

All banks in BUKU 2 banks that have listed show different performance based on the performance in December 2018. Based on the total assets held, the biggest is BRI Syariah Bank which is Rp 38.48 Trillion and the lowest is Ina Perdana Bank, which is Rp 3.85 trillion. The largest capital adequacy ratio (CAR) owned by BTPN Syariah, which is $40.92 \%$ and the lowest is owned by Bank Victoria which is $16.73 \%$.

The purpose of the study was to analyze the level of efficiency in banks in BUKU 2 categories that had listed in IDX, while the specific objectives of the study is to measure the level of efficiency in BUKU 2 bank categories that had listed. The purpose of the research is expected to provide the benefits in the form of a thorough understanding of the level of efficiency in banks in BUKU 2 categories that had listed, dynamically in the short term and long term.

\section{MATERIALS AND METHODS}

According to Hadad et al. [6,7], there are several approaches that can be used to explain the relationship of input and output of financial institutions, namely the production approach, intermediary approach, and asset approach [6,7]. This intermediary approach sees financial institutions as intermediaries. These financial institutions change and transfer financial assets, from excess funds to units that are underfunded. Output in this approach is to measure through credit loans and financial investments, whilst institutional inputs are labor and capital costs and interest payments on deposits. Basically the intermediary approach is complementary to the production approach. The intermediary approach describes banking activities as transforming money borrowed from depositors into money lent to debtors.

The thinking framework of this study was developed from several previous studies relating to the assessment of efficiency in commercial banks based on an intermediary and production approach. Based on the research, it can be explained that the research carried out measurement of the level efficiency banks in BUKU 2 go public that has been listed using Data Envelopment Analysis (DEA). The study design was carried out using a descriptive approach using secondary data. The analysis is done by using Data Envelopment Analysis (DEA) to find out the value of efficiency banks in BUKU 2 go public. The approaches are used to determine the efficiency value, namely the intermediary approach. The input and output variables for the two approaches area) Input Variables : Labor Costs, Third Party Funds, Fixed Assets; b) Output Variables : Total Loan, Operational Income, and Current Assets.

Efficiency analysis uses Data Envelopment Analysis techniques. Data Envelopment Analysis (DEA) is a mathematical program optimization method that measures the efficiency of a Decision Making Unit (DMU) technique, and compares it relative to other DMUs. DEA analysis techniques are specifically designed to measure the relative efficiency of a DMU in conditions of many inputs and outputs. The relative efficiency of a DMU is the efficiency of a DMU compared to other DMUs in the sample using the same type of input and output. DEA formulates DMU as a fractional linear program to find a solution, if the model is transformed into a linear program with the weight values of input and output [8].

This research was conducted in March to April 2019 of eighteen banks in BUKU 2 categories in Indonesia that had listed or go public. The study was conducted in Jakarta using secondary data with a range of years from 2014 to 2018. As for the object of research are 18 (eighteen) banks in BUKU 2 in Indonesia that had listed or go public.

\section{RESULTS}

The analysis has been completed, using the Constant Return to Scale (CSR) model which is represented by the CCR value and the VRS Variable Return to Scale (VRS) model which is represented by the BCC value. In the CSR model it is assumed that the ratio between the addition of input and output is the same (constant return to scale). Additionally, if there is an additional input of a certain amount, then the output will increase by a certain amount as well. Another assumption used in this model is that each company or Decision Making Unit (DMU) operates on an optimal scale. For the VRS model, adding an input of a certain size will not cause the output to increase by a certain size, it can be smaller or larger. Increasing proportions can be increased return to scale (IRS) or can be a decreasing return to scale (DRS) [9].

The results of research conducted in 2014 using the CSR model, followed by either the input or output approach 
which achieved by four banks with optimum efficiency, namely Ina Perdana Bank, Bank of India, Nationalnobu Bank, Woori Saudara Bank. In 2015, there were only three banks that achieved optimum efficiency, namely Ina Perdana Bank, Bank of India, QNB Indonesia Bank. Further, in 2016 achieved by Ina Perdana Bank, Bank of India and Sinarmas Bank, and in 2017 achieved by Ina Perdana Bank and Victoria Bank. Whereas in 2018, there are four banks, namely BPTN Syariah, QNB Indonesia Bank, Victoria Bank, Woori Saudara Bank.

The next analysis is carried out using the VSR model, using either the input or output approach, so there is generally no significant difference with the analysis carried out using the CSR model. The differences in the results were occurred in 2014, where the results of the analysis with the VSR model are six banks that achieve optimum efficiency values, i.e. BTPN Syariah Bank, Ina Perdana Bank, Bank of India, Nationalnobu Bank, Victoria Bank and Woori Saudara Bank. Meanwhile, in 2015 there were four banks that achieved optimum efficiency values, namely Ganesha Bank, Ina Perdana Bank, Bank of India Bank and QNB Indonesia Bank. In 2017 the number of banks that achieved optimum efficiency with the VSR model amounted to four banks, namely Capital Bank, Ina Perdana Bank, Nationalnobu Bank, and Victoria Bank. And in 2018 the number of banks that achieved optimum efficiency with the VSR model amounted to eight banks, namely BRI Agro Bank, BRI Syariah Bank, BTPN Syariah Bank, Capital Bank, Jtrust Bank, QNB Indonesia Bank, Victoria Bank, and Woori Saudara Bank.

Furthermore, the results of the analysis carried out also provide results of several banks that become a reference or reference for efficiency. In 2014, banks that were referred to as efficiency level were Nationalnobu Bank and Bank of India, in 2015 banks were made a lot of efficiency references were QNB Indonesia Bank, Ina Perdana Bank and Bank of India. In 2016, there are three banks that become efficiency references, namely Sinarmas Bank, Ina Perdana Bank and Bank of India, in 2017 there were two banks, namely Ina Perdana Bank and Victoria Bank. And in 2018 there are two banks, namely Bank Woori Saudara, and BTPN Syariah Bank.

The results of research produced in general have results that are in line with what has been done by some previous studies regarding the measurement of efficiency in banks in Indonesia. But what distinguishes this research from other studies is that it is located on the object being analyzed. Other research regarding the level of efficiency of banks in Indonesia is also done by Rubeda [10]. This study aims to analyze the efficiency of banks in Indonesia for the period 2007-2009. The analytical tool used is Data Envelopment Analysis (DEA). Data is sourced from financial statements of commercial banks published by Bank Indonesia. The results of the DEA analysis show that in general commercial banks in Indonesia have not yet reached the level of efficiency, especially national private banks. This is evidenced by 21 commercial banks, only 7 banks that have achieved efficiency, consisting of 2 state banks, namely BRI and BTN, 3 banks namely West Java BPD, East Java BPD, 1 private bank, namely commercial banks and 1 Islamic bank, Muamalat Bank. This fact shows that the performance of banks in Indonesia is still not maximal with the use of waste on several input variables used by banks in their economic activities [10].

Analysis of efficiency in addition to commercial banks has also been carried out on Rural Credit Banks (BPR) in the Jabodetabek area by using the acceleration of Data Envelopment Analysis by Hartono [11]. The purpose of the study is to measure and analyze the level of efficiency of BPRs and formulate steps that can be done to improve the efficiency of BPR in the variables studied. In this study the scope was Conventional Rural Banks in the Jabodetabek area in the period 2005-2007 [11].

Efforts to improve, to improve efficiency, which is characterized by the lowest efficiency value, need to be done by several banks in the form of increased output from the resources they already have. Based on the CRS model approach, using the input and output approach, the bank is based on the results of the analysis that has been carried out, so there are several banks that have the lowest value, Maspion Bank (2014-2015), Artha Graha International Bank (2016-2017), Bumi Arta Bank (2018). The results of the analysis using the VRS model, the banks that have the lowest efficiency value are Artha Graha International Bank (2014-2018), Bumi Arta Bank (2015-2018).

\section{CONCLUSIONS}

Based on the intermediary approach, the results showed that in 2014, there was two national private banks (Bank Ina Perdana and Bank Nationalnobu), and two foreign banks (Bank of India and Bank Woori Saudara) that shown the level of efficiency. In 2015, there were only two foreign banks (Bank QNB Indonesia and Bank of India) and only one national private bank (Bank Ina Perdana) that show the level of efficiency. In 2016, there was three banks that achieved efficiency, one was foreign bank (Bank of India) and the other was two national private bank (Bank Ina Perdana and Bank Sinarmas). In 2017, there were two national private bank (Bank Ina Perdana and Bank Victoria) that shown the level of efficiency. And in 2018, there was four bank has achieved efficiency: one shariah bank (Bank BTPN Syariah), two foreign bank (Bank Woori Saudara and Bank QNB Indonesia) and one national private bank (Bank Victoria)

Shariah bank was able to achieve the best level of efficiency (Bank BTPN Syariah in 2018). Most of the foreign banks were able to achieve the level of efficiency (Bank Woori Saudara in 2014 \& 2018, Bank QNB Indonesia in 2015 \& 2018, Bank of India in 2014, 2015 \& 2016). In the national private bank, there were only four banks that able to achieve, which were Bank Ina Perdana (2014, 2015, 2016 \& 2017) Bank Victoria (2017 \& 2018), Bank Nationalnobu (2014) and Bank Sinarmas (2016). There was no state-owned bank, achieved the level of efficiency.

\section{REFERENCES}

[1] Financial Services Authority, 2014, Available from: Http://www.ojk.go.id, Indonesian Banking Statistics

[2] Financial Services Authority, 2015, Available from: Http://www.ojk.go.id, Indonesian Banking Statistics 
[3] Financial Services Authority, 2016, Available from: Http://www.ojk.go.id, Indonesian Banking Statistics

[4] Financial Services Authority, 2017, Available from: Http://www.ojk.go.id, Indonesian Banking Statistics

[5] Financial Services Authority, 2018, Available from: Http://www.ojk.go.id, Indonesian Banking Statistics

[6] M. D. Hadad, W. Santoso, E. Mardanugraha, and D. Illyas, "Parametric Approach to Indonesian Banking Efficiency," Research Paper, No. 4/5, Bank Indonesia Financial System Stability Bureau, 2003.

[7] M. D. Hadad, W. Santoso, E. Mardanugraha, and D. Illyas, "Efficiency Analysis of the Indonesian Banking Industry: Use of the Nonparametric Data Envelopment Analysis (DEA) Method," Research Paper, No. 7/5, Bank Indonesia Financial System Stability Bureau, 2003.
[8] M. J. Farrell, “The Measurement of Productive Efficiency,” Journal of The Royal Statistical Society, vol. 120, pp. 253-81, 1957.

[9] T. J. Coelli, D. S. P. Rao, and G. E. Battese, Introduction to Efficiency and Productivity Analysis, Boston: Kluwer Academic Publishers, 1998.

[10] K. Rubeda, "Bank Efficiency Level in Indonesia," Dynamics of Accounting, Finance and Banking, vol. 1, no. 2, pp. 175-200, November 2012.

[11] I. Hartono, S. Djohar, and H. K. Daryanto, "Efficiency Analysis of Rural Credit Banks in the Jabodetabek Region with a Data Envelopment Analysis Approach," Journal of Management \& Agribusiness, vol. 5, no. 2, October 2008.

APPENDIX

TABLE 1. BUKU 2 BANK FINANCIAL RATIO (IN \%)

\begin{tabular}{|c|c|c|c|c|c|c|c|c|}
\hline \multirow[t]{2}{*}{ FINANCIAL RATIO } & \multicolumn{3}{|c|}{$\begin{array}{c}\text { Conventional Banks } \\
\text { BUKU } 2\end{array}$} & \multirow[b]{2}{*}{2018} & \multicolumn{4}{|c|}{$\begin{array}{l}\text { Sharia Banks } \\
\text { BUKU } 2\end{array}$} \\
\hline & 2015 & 2016 & 2017 & & 2015 & 2016 & 2017 & 2018 \\
\hline Capital Adequacy Ratio (CAR) & 23.05 & 23.72 & 26.47 & 26.28 & 14.96 & 17.78 & 18.68 & 22.12 \\
\hline $\begin{array}{l}\text { Operational Cost / Operating } \\
\text { Income (BOPO) }\end{array}$ & 85.48 & 85.38 & 86.33 & 86.21 & 96.03 & 91.58 & 92.21 & 85.67 \\
\hline ROA & 1.62 & 1.66 & 1.57 & 1.54 & 0.48 & 1.08 & 0.94 & 1.58 \\
\hline Loan to Deposit Ratio (LDR) & 97.81 & 98.04 & 91.22 & 94.03 & 90.55 & 89.21 & 80.18 & 78.51 \\
\hline
\end{tabular}

(Source: Indonesian Banking Statistics - Financial Services Authority) [1,2,3,4,5]

TABLE 2. SUMMARY OF 2018 FINANCIAL RATIOS OF EIGHTEEN BUKU 2 BANKS Go PUBLIC

\begin{tabular}{|c|c|c|c|c|c|c|c|c|}
\hline No & Bank Name & $\begin{array}{c}\text { Asset } \\
\text { (Milion } \\
\text { Rupiah) }\end{array}$ & CAR (\%) & $\begin{array}{r}\text { NPL } \\
\text { Gross } \\
(\%)\end{array}$ & $\begin{array}{r}\mathrm{ROA} \\
(\%)\end{array}$ & $\begin{array}{r}\text { ROE } \\
(\%)\end{array}$ & $\begin{array}{r}\text { BOPO } \\
(\%)\end{array}$ & $\begin{array}{r}\mathrm{LDR} \\
(\%)\end{array}$ \\
\hline 1 & BTPN Syariah Bank & $12,039,275$ & 40.92 & 1.39 & 12.37 & 30.82 & 62.36 & 95.60 \\
\hline 2 & Victoria Bank & $28,360,624$ & 16.73 & 3.48 & 0.33 & 3.41 & 100.24 & 73.61 \\
\hline 3 & Mestika Dharma Bank & $12,175,309$ & 34.58 & 2.33 & 2.96 & 9.01 & 68.09 & 86.93 \\
\hline 4 & BRI Agro Bank & $23,363,910$ & 28.34 & 2.86 & 1.54 & 5.80 & 82.99 & 86.75 \\
\hline 5 & QNB Indonesia Bank & $20,490,684$ & 26.50 & 2.49 & 0.12 & 0.42 & 99.43 & 72.59 \\
\hline 6 & BRISyariah Bank & $38,480,749$ & 29.72 & 6.73 & 0.43 & 2.49 & 95.32 & 75.49 \\
\hline 7 & Artha Graha Internasional Bank & $26,109,836$ & 19.80 & 5.99 & 0.27 & 1.43 & 97.12 & 77.18 \\
\hline 8 & Woori Saudara Bank & $29,782,514$ & 23.04 & 1.72 & 2.59 & 13.01 & 70.39 & 145.26 \\
\hline 9 & Sinarmas Bank & $30,803,601$ & 17.60 & 4.74 & 0.25 & 1.12 & 97.62 & 84.24 \\
\hline 10 & Bank of India & $3,896,760$ & 39.46 & 4.90 & 0.24 & 0.94 & 97.65 & 99.48 \\
\hline 11 & Jtrust Indonesia Bank & $17,845,096$ & 14.03 & 4.26 & -2.25 & -29.13 & 116.32 & 77.43 \\
\hline 12 & MNC International Bank & $10,854,855$ & 16.27 & 4.10 & 0.74 & 5.43 & 93.51 & 88.64 \\
\hline 13 & Bumi Arta Bank & $7,297,274$ & 25.52 & 4.45 & 1.77 & 6.81 & 81.43 & 84.26 \\
\hline 14 & Capital Bank & $18,019,614$ & 18.66 & 2.95 & 0.90 & 8.46 & 92.11 & 51.96 \\
\hline 15 & Ganesha Bank & $4,497,122$ & 31.85 & 4.25 & 0.16 & 0.51 & 97.57 & 87.81 \\
\hline 16 & Ina Perdana Bank & $3,854,174$ & 55.03 & 2.43 & 0.50 & 0.97 & 93.06 & 69.28 \\
\hline 17 & Nationalnobu Bank & $11,793,981$ & 23.27 & 0.97 & 0.42 & 3.39 & 94.77 & 75.35 \\
\hline 18 & Maspion Bank & $6,694,024$ & 21.28 & 2.14 & 1.54 & 6.35 & 87.25 & 100.87 \\
\hline
\end{tabular}

